\title{
FROM GLOBAL DISCOURSE TO LOCAL ACTION: THE MAKINGS OF A SEXUAL RIGHTS MOVEMENT?
}

\author{
Jonathan Garcia \\ Richard Parker \\ Columbia University - United States of America
}

\begin{abstract}
This paper focuses on the development of discourses around sexual rights, linking tendencies in official global dialogues with national and local realities. Recognizing some of the factors that have facilitated or impeded discourses and action to promote sexual rights around the world, we explore the principles and processes of framing sexual rights and sexual citizenship. We consider political opportunity and the mobilization of resources as important as cultural and emotional interpretations of sexual rights in conceptualizing a "sexual rights movement". Throughout the paper we question whether a movement based on solidarity can be forged between different social movements (i.e., feminist movements, HIV/AIDS movements, LGBT movements, etc.) that are advocating for distinct sexual rights. While theoretically sexual rights range from protection from sexual violation to the celebration of sexual pleasure, in reality the agendas of sexual rights movements are still largely fragmented, heteronormative, and focused on negative rights.
\end{abstract}

Keywords: global discourse, local activism, sexual rights, social movements.

Resumo: Este artigo enfoca o desenvolvimento de discursos que circundam os direitos sexuais juntando tendências em diálogos globais oficiais com realidades nacionais e locais. Reconhecendo alguns fatores que têm facilitado ou impedido discursos e ações que promovam direitos sexuais ao redor do mundo, nós exploramos os princípios e processos onde se enquadram os direitos sexuais e a cidadania sexual. Nós consideramos que as oportunidades políticas e a mobilização de recursos são tão importantes para a conceitualização de um movimento pelos direitos sexuais quanto as interpretações culturais e emocionais dos direitos sexuais. Ao longo deste artigo, nós questionamos se um movimento baseado na solidariedade pode ser forjado entre movimentos diferentes (por exemplo, movimentos feministas, HIV/Aids, movimentos $G L B T$, etc.) que estão reivindicando direitos sexuais distintos. Enquanto teoricamente os direitos sexuais vão desde a proteção da violação sexual até a celebração do 
prazer sexual, na realidade, as agendas dos movimentos pelos direitos sexuais estão ainda muito fragmentadas, heteronormativas e enfocadas em direitos negativos.

Palavras-chave: ativismo local, direitos sexuais, discurso global, movimentos sociais.

In the late twentieth century, globalization has been characterized by accelerating exchanges of social, cultural, political and economic capital across country borders (see, for example, Appadurai, 1996; Castells, 1996, 1997, 1998; Giddens, 1990, 1991; Harvey, 1989; Waters, 1995). Evolving technologies have transformed the modes of production and the means of communication between individuals, social groups, and interacting cultures (Appadurai, 1996; Castells, 1996). As nation-states become more integrated into the global economy, emerging challenges have not been limited to the political-economic realm, as cultural and social exchanges between countries have allowed for a reflection on the norms and rules that were once second-nature and are still seldom questioned.

As more focus is given to social and political debates questioning the deeply rooted traditions of patriarchy (Castells, 1997), researchers and activists have become more aware of the implications of gender and sexual norms on the health and general welfare of populations. This article draws attention to the dialogue between global definitions of sexual rights and local understandings and claims to such rights. We review the current literature on the emerging discourses of "sexual rights" in the global arena, and explore the ways in which this global debate maps out on the local level. Interpersonal social and cultural norms are particularly important in determining the way in which sexual and gender roles are played out on the local level. This is especially crucial for the dialogue between a burgeoning sector of civil society that endeavors to, on one hand, interpret and push the envelope by drawing from the global discussions on 'sexual rights', and more importantly brings forth the personal experiences of those who are marginalized and denied fundamental rights on the basis of gender, sexuality, identity, race, class, and so forth. The impact of this discussion over 'sexual rights' matters most where the 'personal becomes political'. This dialectic between the personal and the political is complicated by the layers of meaning given to the term 'sexual rights' in different contexts and cultures. And this dialectic is even more complex considering the amplitude of the umbrella category "sexual rights", which encompasses many aspects of sexuality that affect populations with differing identities and agendas. 
Can the struggle for sexual rights be deemed a social movement? This question is complicated because the domain of sexual rights is being defined and constructed at a point of intersection between a number of movements (feminist, gay and lesbian, queer, trans, HIV/AIDS, etc.) that for much of the past 20 years have evolved in quite separate ways. Part of the challenge (and the unanswered question) is whether a notion of sexual rights might be constructed that can be broad enough to bring these movements together in a broader alliance or coalition, without being so broad that it loses its political edge and fails to serve any real purpose.

In the spirit of solidarity, the act of defining notions of "sexual rights" as a transnational social movement with deepening roots through national and local networks is a veritable challenge in the beginning of the twenty-first century for those advocating for different aspects of sexual rights. Solidarity has proven to be an extremely effective way to mobilize, gain legitimacy in the political realm and to achieve meaningful policy and socio-cultural transformations. Much of the social movement literature has questioned why, when, and how social movements emerge - some giving more weight to structural forces such as political opportunities (McAdam; McArthy; Zald, 1996; Tarrow, 1998) while more recently the literature has highlighted the importance of the socio-cultural realm and the redefinition of the life-worlds where contention is not focused solely on the state or economic centers (Alvarez; Dagnino; Escobar, 1998; Parker et al., 2004). Later social movement theory has given great importance to the dynamics through which contention is framed (Benford; Snow, 2000) and to the role of embodiment and emotions in the mobilization of collectives with common goals and experiences (Brown et al., 2004; Parker, 1996; Polletta, 1998; Polletta; Jasper, 2001). Theorists of popular participation and education, the most commonly known being Paulo Freire, have emphasized the importance of the use of a language that emerges from the people, while questioning social texts that emerge, and are sometimes imposed, from above (Freire, 1973). Thus, considering socio-cultural norms, political opportunity structures and framings of rights allows for a theoretical conceptualization of a 'sexual rights movement' that is defined by global dialogues as well as by local contexts and embodied realities.

This movement has certainly been driven and thwarted by political opportunity structures (e.g., regime changes) as well as by the emotional desire for freedom from and freedom for sexual autonomy. The issues of framing emerge both in cultural contestations of what is acceptable behavior and 
identification and the dynamics of opposition over what is deserved and claimed as a sexual right depends on negotiations of time and space. We argue that in this stage of globalization (when discourses of human rights co-exist in an uncomfortable relationship with the proliferation of religious fundamentalisms and neo-liberal economic policies) the limits of our personal autonomy have been re-drawn (Castells, 1997). Movements on behalf of sexual rights have encountered a powerful reactionary response in traditionalist movements rallying for conservative family values and religious beliefs (Lamberts-Bendroth, 1999; Ratzinger, 2003, 2004; Marty, 1988). In the third decade of the HIV/AIDS pandemic, ideologies, rights, and identities have mediated the issues around which resources are mobilized and the policies that are advocated for throughout the world (Heywood, 1999). In light of this, a connection has also been made between discourses around these emerging sexual rights and public health (World Health Organization, 2002).

For one, global social movements have played a crucial role in shaping the intersections between the political economy and the embodiment of HIV/AIDS, other health-relates problems (Brown et al., 2004), education and other the distribution of other social goods. The urgency of the HIV/AIDS pandemic has been an indelible force in placing previously unquestioned sexual and gender norms under the looking glass, revealing that the transmission of a microscopic biological entity is in fact driven by social, cultural, political and economic forces (Berkman et al., 2005; Ford; Odallo; Chorlton, 2003; Gamson, 1989; Parker, 1996, 2000). HIV/AIDS has drawn attention to certain populations that are categorized, medicalized and objectified in terms - including commercial sex workers, men who have sex with men, and intravenous drug users - that have been used to target risk groups in behavioral interventions (Farmer; Connors; Simmons, 1996; Mann; Tarantola; Netter, 1992; Parker 2001). In the name of objectivity, these groups have often been blamed and shamed as responsible for the spread of the epidemic (Maluwa; Aggleton; Parker, 2003; Parker; Aggleton, 2003). More recently, the globalization of conservative ideologies emanating primarily from the United States, have increased vulnerability (especially of women and children in poor countries of the Global South) to the epidemic by advocating for abstinence-only education and stressing the importance of abstinence until marriage and fidelity during marriage over condom use as means of prevention from HIV infection (Arnold et al., 1999; Girard, 2004; Jones, 2002). Interestingly enough, the structural and cultural contextualization of biomedical explanations parallel the processes of socio-cultural globalization; 
and the relationships between sexual rights and sexual health are shaped by how we have come to interpret the historical impacts of the pandemics of HIV/ AIDS, the intentional infliction of shame, stigma and discrimination, cultural imperialism, and the preeminence of the economic rights over human life.

The embodied realities of illness and of the denial of access to essential public services bring home the importance of considering gender and sexuality as factors significant as poverty, race, ethnicity and class in the contemporary definition of rights and citizenship. Because social norms related to sexuality are enforced and perpetuated by political, economic, social and cultural spheres of power - a change towards greater equality between genders and respect for the citizenship of sexual minorities requires a re-imagining of what constitutes a human right. Rights are no longer limited to the protection of private property or of political and civil liberties, as the term has been extended to other realms of human life. The emergence of sexual rights has highlighted the importance of considering culture and religion, for example, as important as government policy as areas of contention and targets for intervention. Because rights that are not 'officially' recognized by governments or international governing institutions (e.g. the United Nations) are sometimes dismissed as merely rhetorical discourses, the race to include sexual rights within formal documents generated by such institutional structures has dominated the agenda of international activists (Corrêa; Petchesky, 1994; Corrêa; Sen, 1999; Petchesky, 2000, 2003). Opponents have reacted negatively to the classification of sexual diversity and sexual pleasure as human rights, by claiming that legitimizing aberrant lifestyles jeopardizes the family and religious traditions for generations to come (Girard, 2004). The media has played a major role in sensationalizing certain issues such as trafficking in women and children, same-sex marriage, female genital mutilation, and HIV/AIDS. In reality, although sexuality affects every aspect of human development and social interaction, the topic been actively repressed in spaces such as educational and health systems in many parts of the world.

The HIV/AIDS pandemic is a major, albeit not the only, driving force in the global fight for sexual rights. Social mobilization for 'sexual rights' and against patriarchal and fundamentalist socio-cultural norms can be traced back to feminist and gay rights movements of the 1960s, although the term itself was almost never used until the mid-1990s (Parker, 1997, 2000; Petchesky, 2000). While the globalization of social and cultural understandings of rights has played an integral role in furthering the seminal work of social movements born in the middle of the twentieth century - a closer look at the current state of global 
transformation reveals that homegrown, grassroots movements and networks may often be more important than transnational mobilization in transforming social norms (Tarrow, 1998). Thus, it is also important to highlight the somewhat complicated development of civil society during last half of the twentieth century when many countries throughout the world transitioned from authoritarian to democratic regimes:

Emergent civil societies in Latin America and Eastern Europe are credited with effective resistance to authoritarian regimes, democratizing society from below while pressuring authoritarians for change. Thus civil society, understood as the realm of private voluntary association, from neighborhood committees to interest groups to philanthropic enterprises of all sorts, has come to be seen as an essential ingredient in both democratization and the health of established democracies. (Foley; Edwards, 1996, p. 38).

Global transformations resulted in a vast variation in the definition of the public and private spheres, and more specifically in what were considered fundamental principles of citizenship - principles that would have been impossible to claim during earlier periods of authoritarian or military regimes in many parts of the world.

Brazil and South Africa provide interesting examples of how solidarity between social movements can be forged during periods of intensive political struggle. During the redemocratization of Brazil in the 1980s, a variety of social movements (including the sanitary reform movement, the labor unions, gay rights movements, the Catholic Church, among others, and many non-governmental organizations) came together during a time of opening in civil society (abertura) in the spirit of solidarity on behalf of citizenship for all. This partly explains why the 1988 Constitution is extremely detailed and rife with references to a variety of rights, including gender equality (Pintaguy, 2002). Nevertheless the Brazilian Constitution does not protect against discrimination based on sexual orientation.

On the other hand, in South Africa, in the struggle against apartheid diverse aspects of civil society came together to ban discrimination, including that which is based on sexual orientation (Cameron, 1993, 2002). Rev. Desmond Tutu, a prominent leader in the anti-apartheid movement argues that black people were discriminated and blamed for being black, something over which they had no agency, and he made a strong statement that "it is the same with sexual orientation” (Afrol News, 2006). Having fought against outrageous levels of 
discrimination, Rev. Tutu explains that it would make no sense to fight against discrimination based on race without fighting against discrimination against homosexuals (Afrol News, 2006). South Africans have managed to include a broad definition of human rights in their new constitution precisely because of the solidarity that activists from diverse walks of life felt against a highly repressive and violent regime. Even though both Brazil and South Africa had strong alliances between various fronts of civil society, the South African constitution managed to adopt a constitution with a broader definition of human rights. In any case, highly contentious cycles, such as the change from authoritarianism to democracy, provide a political opportunity structure where the definition of human rights can be more easily restructured. Further investigation in this area is necessary to analyze what elements and degrees of openness within civil society create a more favorable atmosphere for solidarity between social movements.

We therefore want to emphasize the importance of 'civil society' in the consolidation of rights and the definition of citizenship. Civil society can be conceptualized as space where cultural norms and the interpretation of rights are defined (Clark; Friedman; Hochstetler, 1998; Foley; Edwards, 1996). Although the notion of rights often conjures the image of the protection of citizens by the state in the form of a social contract, we conjecture that social movements act in the realm of civil society where cultural norms are contested. The goals of social movements advocating for a respect for sexual diversity and gender equality includes changing laws and state policy. But slow and sustained contestation on the local level can perhaps bring about longer-term commitment to sexual rights. The contestation of cultural norms that occurs gradually, over time, can be said to create changes in habitus (Bourdieu, 1998) - potentially making discrimination, stigmatization, and marginalization of sexual diversity more socially problematic. What seems to be a step forward in the legal codification or discursive acceptance of sexual rights may mask injustices that happen in socio-cultural realms and in the private sphere. Legal codification can in fact reduce the effervescence of social movements within civil society that is necessary to bring about long lasting social transformation. To add complexity to this matter, the nature of civil society has changed in the twentieth century due to financing structures and the relationship between the state and non-governmental organizations. Nevertheless, the increase in non-state actors can also reflect the ideologies of financial institutions or even reinforce state level policies through a process often referred to as the co-optation of civil society (Fischer, 1997). 
Thus, the obstacles faced in seeking to advocate for sexual and reproductive rights, range from institutional and infrastructural barriers (including the politics of financial support) to the difficulties of addressing questions of sexuality within the structures of judicial systems, governmental and intergovernmental agencies (Corrêa; Parker, 2003; Petchesky, 2003). But while these structural forces provide or deny rights, it would be a mistake to forget or ignore the importance of local understandings or individual and communal claims to such rights. Without a doubt, sexual violence, oppression and discrimination are among the most serious threats to human security today at every level of societies: at the level of the family, the neighborhood or community, the nation-state, and the international community (Corrêa; Parker, 2003). Thus it is important to focus not only on the 'formal institutionalization' of sexual rights, but also to pay close attention to what some would consider an 'informal' recognition or rejection of sexual rights in the realms of culture and civil society.

Moreover, some discussions about sexuality, sexual health and sexual rights have centered on the embodiment of citizenship (Parker; Barbosa; Aggleton, 2000). These notions have highlighted the complexity of human sexuality especially the tension between recognizing its fluidity, social construction and historical continguency, on one hand, and the need to create categories and identities to 'operationalize' sexual rights, on the other hand. Research on sexuality and gender has discussed the complexities that characterize intimacies of human relationships, whereas international human rights movements, feminist movements, LGBT rights movements, and People living with HIV/AIDS movements have sometimes found it easier to create identities to guide lawmaking, the mobilization of collective action, and the allocation of resources.

On a daily basis, individuals negotiate between different aspects of their "selves" (e.g. the working class, gay, Afro-Caribbean Latino, living in East Harlem with two children). Identities are not only fragmented politically among groups, but this fragmentation is also mapped onto our bodies. While identity politics (Calhoun, 1994) delimit certain dimensions of sexuality for the sake of protection that may comes from belonging to a defined group, a broader human rights perspective has begun to place sexual and reproductive rights within the gamut of fundamental human freedoms (Corrêa; Parker, 2003; Corrêa; Petchesky, 1994; Narrain, 2001; Parker et al., 2004; Petchesky, 2000). This notion of a universal human right is inevitably conflicted with the application of these rights on the ground, where they may encounter cultural and political resistance. Thus, for these rights to be 'operationalized' in a substantive way, 
these forms of resistance should be addressed from below, from grassroots movements, as well as from the top. If we are living in a time when identities are crucial for the definition of rights, then identities must ideally be constituted, articulated and defined through self-representation rather than being represented by others acting as "protectors". Nevertheless, the creation of categories may initiate a reflexive contemplation that may result in the formation of communities that were once unimagined.

In fact, the conception of "sexual rights" was first centered on reproductive rights in order to protect women from violations such as forced sterilization, physical abuse, rape and sex trafficking (Corrêa; Petchesky, 1994; Petchesky, 2003). The definition of "sexual rights" has been broadened by lesbian, gay, feminists, HIV/AIDS activists in order to include the celebration of sexual diversity and sexual pleasure. (Corrêa; Parker, 2003; Parker, 1997, 2000; Petchesky, 2000, 2003). Coming from a number of fronts advocates for sexual rights as well as counter-movements have framed the concept strategically, with varying agendas including that of sexual health.

This work has also been extended on the regional, national and local levels through diverse initiatives focusing on sexual rights. In order to highlight the socio-political importance of international dialogues and local understandings of sexual rights, it is important to bring together several ethical principles and theoretical frameworks that begin to deepen the meaning behind the term "sexual rights". Several lines of theoretical thinking that have grown to complicate theories of rights include (but are not limited to) the discussion of sexual citizenship, cultural imperialism and the global proliferation of sexual rights. Behind these theories lie fundamental struggles for equality, freedom, and human dignity - where ownership of the body is the value premise. In the following section we describe some of these principles and their implications on the mobilization on behalf of sexual rights as an effort that will most effectively promote social change - assuming that these principles are defined, understood, and claimed as rights on the local and global scale.

\section{Framing sexual rights as human rights}

Sexual rights are said to embrace human rights that are already recognized in national laws, international human rights documents and other consensus documents. These include the right of all persons, free of coercion, discrimination 
and violence, to: the highest attainable standard of health in relation to sexuality, including access to sexual health including reproductive health care services; seek, receive and impart information in relation to sexuality; sexuality education; respect for bodily integrity; choice of partner; decide to be sexually active or not; consensual sexual relations; consensual marriage; decide whether or not, and when to have children; and pursue a satisfying, safe and pleasurable sexual life. The responsible exercise of human rights requires that all persons respect the rights of others (World Health Organization, 2002).

On one level, sexual citizenship can be associated to having fundamentals right to free expression and just desert. Freedom of expression usually refers to expression in the public domain, while sexuality and gender relations have typically been relegated to the private sphere. In general, the types of rights that are associated with the public sphere include political, civil, and economic liberties, which are distributed and protected by the state. The idea of sexual rights brings forth the ability to express sexual diversity in the public sphere-especially if political, civil or economic rights are contingent on sexual orientation and gender, for example. Sexual rights, in this sense can include the right to divorce, the right to marry, the right to choose sexual partner(s), the right to be protected from violence, the right to inherit, the right to adopt, and the rights to receive public services such as education and healthcare, an so forth. Often sexuality is lurking but is not acknowledged as a factor that colors our basket of fundamental rights. Thus, the conventional language of rights (if sexual rights are not included) is often heteronormative and sexist by nature - excluding parts of our selves that behave, identify, or have interpersonal relations outside of sociocultural norms. At some level, one of the strategic uses of the phrase "sexual rights” is precisely to undercut or question this heteronormativity.

If our fundamental rights are contingent on sexuality or gender, are they rights or are they privileges? We argue that a public distribution of goods that does not abide by the principle of equality is inherently unjust, and that 'rights for some' equates to rights for no one. If either through legal mechanisms or through stigmatization and shaming a transgender woman does not have access to health services or to employment other than sex work, then we can see concretely how infringing on sexual rights can also deny economic rights, political and civil rights. The rhetoric of rights loses its meaning if it is applied arbitrarily or according to factors such as ethnicity, gender, sexuality, class, etc. Thus, the idea of sexual rights takes into account the importance of considering sexual diversity and gender equality as key to reaching true citizenship. 
On another level, it is important to re-question the division of private and public domains. Sexual violence, rape, and abuse often happen in closed quarters, and even within the sanctity of the heterosexual marriage. Who should prevent these types of rights violations? Should the state be allowed in the bedroom? Should the state become a form of barrier protection during sexual intercourse? Here is where the limitations of legal protection are most salient. What happens to rights when the state cannot clearly administrate their distribution? In many contexts, women are considered to be the property of men - essentially categorizing women as objects bereft of human dignity. These matters are further normalized as cultural or social norms in some contexts. This discussion goes without further explanation because it seems clear, prima facie, that distributing rights differentially according to gender denies citizenship to women. Even so, some argue that a cultural right (the right to express one's culture) supercedes the right to gender equality (Saiz, 2005) This argument not only assumes that any established social order is inherently just, but it also highlights the necessity of classifying sexual rights as fundamental and inalienable.

The same reasoning can be applied to inequality based on sexual orientation or on being transgender, for example. Although diverse sexualities and forms of expression are considered abominations and dangerous to the social thread in almost all societies (primarily through the influence of fundamentalist and conservative fronts), rights should not be denied to a person because of their sexual identity, unless a harm to others can be coherently argued. Let us steer clear of those that attempt to equate sexual diversity with pedophilia and bestiality in order to avoid muddling the waters. Whereas pedophilia and bestiality may be seen to violate human or animal rights, being homosexual and/or transgender are individual lifestyles with no harm to other individuals. We argue that exposing society to diversity is not a moral crime - but conversely, dehumanizing a person based on sexuality does violate equality, freedom and human dignity.

Now where does the right to sexual pleasure fit into the equation? Within the discussion of sexual rights and citizenship, theorists have applied the distinction between a "negative" right and a "positive" right (Parker, 1997; Petchesky, 2000). The work of activists and researchers has focused primarily on redressing harm or protecting women from violence and abuse, where as others have called for a movement towards a "positive" conception of sexual rights that respects freedom for sexual diversity and self-expression as fundamental to human integrity (Petchesky, 2000). Positive rights are said to enable the expression of sexual diversity and pleasure. Recalling the argument that most 
aspects of human life, thought, and interpersonal interactions are imbued with sexuality, why keep sexuality in the closet? Granted that the argument for positive sexual rights assumes foresight into what types of conditions will enable sexual expression in the future, after a simple mind experiment it seems that working towards the ethical obliteration of sexual repression is both integral and true to human existence. Consider the concrete examples of cultural norms that deny women's sexual pleasure through female genital mutilation (which can be reframed biologically as genital excision) or that denigrate women for displaying pleasure during sexual intercourse. These examples are more clearly imaginable as violations of human integrity. If we can expand our vision of humanity beyond heterosexuality, we can make the same argument for denying the ethical enjoyment of diverse non-heteronormative forms of sexual pleasure. The qualification of enjoyment as "ethical" here clarifies that conduct we are referring to a form of sexual diversity that abides by the harm principle (i.e. as long as you are not harming another individual or her/his autonomous choice then an act can be considered ethical).

How can a society enforce the right to sexual pleasure? Again, we stress the fact that our argument is not simply about rights that are protected by the state (although we do claim that institutions and laws that repress sexuality cause various forms of harm). The idea of sexual pleasure, its definitions, its language, its expression, all typically come from below, from the local context where people experience life. These interpretations emerge from cultural systems of meaning and significance that are a mélange of popular culture intersecting with elite culture, mechanically reproduced and ideologically mediated. Social, cultural, religious, bioscience, and other non-state actors are mainly responsible for respecting the right to sexual pleasure, again, by abiding by the principles of equality, freedom and human dignity.

Some discussions with regard to sexual pleasure have resulted mainly in activist circles. Although there has been some discourse about "freedom from coercion, discrimination, and violence", Neha Patel comments that even in the activist community "the language of sexual pleasure has been restrictive, fearbased, and limiting”, setting guidelines for normative definitions of pleasure and not about what brings about personal pleasure because that would be considered "illegitimate" and "indulgent” (Patel, 2006, p. 67). Some activists, such as Patel, have been working on the ground level and on the internet to bring about dialogue about how sexual pleasure influences personal well-being. The South and Southeast Asia Resource Centre on Sexuality created an e-forum that ran from 
October to December, 2005 in order to open a dialogue that gave legitimacy to the sexual pleasure as an integral part of human life. The discussion, Patel (2006, p. 68) explains, "was for those interested in critiquing and analyzing the discourses around sexual pleasure, sexuality and rights". Although there were a variety of participants, they were limited to people who spoke English and who had access to the internet. Another difficulty encountered was the "need for a language on pleasure, [as] many terms related to sexuality do not often translate into local meanings" (Patel, 2006, p. 68). The subjectivity of sexual pleasure results in a theoretical as well as in a lived complexity in discussing it as an elemental part of sexual rights. The tendency of categorizing rights does not easily lend itself to the multiple and fluid interpretations of pleasure and desire. In analyzing the discourses collected through this e-forum, several tendencies emerged around the moralization, normalization, and moderation of sexual pleasure; and more importantly, some discussants were afraid that an excess in sexual pleasure would harm others (Patel, 2006).

Positive rights that enable expression and negative rights that redress harm becomes more theoretically difficult to distinguish when enabling sexual rights are interpreted as a way to avoid foreseeable harm (such as the illness and psychological implications of sexual repression) in the future, thus becoming negative rights that redress harm within a long-term horizon. We can make this distinction more clearly "when a positive conceptualization of sexual rights implies that sexual rights are good in and of themselves in the way that liberty and life are inalienable. In these terms, honoring sexual rights is justified as celebrating an innate human freedom” (Parker et al., 2004, p. 374; see also Corrêa; Petchesky, 1994; Petchesky, 2000, 2003). The emerging (or evolving) social movement for sexual rights ideally takes into account both positive and negative rights. Issues such as violence against transsexuals and rape of women should be redressed through legal as well as socio-cultural intervention. Sexual education and same-sex marriage can be categorized more easily as positive rights because they enable the sexual health of the person (Parker et al., 2004). From an early age, many children learn that the greatest insult is to be called 'gay' (or 'queer', etc.). The state has a moral obligation to offer comprehensive sexual education for youth (Cash et al., 2001) that addresses issues such as the stigmatization of diverse sexualities in order to enable sexual rights in the future.

As the result of an extended series of consultations the WHO has developed a set of working definitions of sexuality, sexual health and sexual rights that have increasingly been adopted by a range of international agencies (World 
Health Organization, 2002). These definitions have drawn on various sources (see Girard, 2004) including international law, international consensus agreements on sexual and reproductive health and rights, and the work of a number of experts and organizations in the field of sexuality. These definitions take a broad approach to sexuality, including topics such as sexual orientation, sex education, reproduction, and marriage. Within the WHO framework, "sexuality" is a central aspect of life at all ages and encompasses sex, gender identities and roles, sexual orientation, eroticism, pleasure, intimacy, and reproduction. Sexuality is said to be experienced and expressed in thoughts, fantasies, desires, beliefs, attitudes, values, behaviors, practices, roles and relationships. While sexuality can include all of these dimensions, not all of them are always experienced or expressed. Sexuality is influenced by the interaction of biological, psychological, social, economic, political, cultural, ethical, legal, historical, and religious and spiritual factors (World Health Organization, 2002).

The discourses in these domains exemplify cross-cutting tensions in the field of sexual rights, including the distinction between public and private spheres, the separation of the church and state, and moral obligations that derive from the state as well as from civil society (and that permeate family life), and the difficulties in finding a common language in discussing sexuality and sexual rights. This discursive complexity impacts sexual rights 'social movements' by obfuscating the framing of principles that are being advocated. Thus, we have provided a simple overview of several principles and dimensions that can be included in the category of "sexual rights." The most important issue is how to consolidate a social movement when there is a clear gradient with the "protection of women from rape and violence' on the more conservative side and with the inclusion of 'sexual pleasure' on other, more progressive, end of the spectrum. The definition of sexual rights is crucial for strategic framing and has created some dissonance between those advocating for negative rights and those who want to push the envelope by including positive sexual rights.

In the last part of this paper, we describe some of the global and local discussions and action around sexual rights and citizenship. Before discussing some of the literature on local interpretations and the uses of this 'sexual rights' framework on the ground, we focus on the international debate. The organization of this argument addresses the attempts of advocates to include the terms related to "sexual rights" in official international dialogues. Although we continue to highlight the importance of grassroots movements and their role in bringing forth issues that have been categorized as sexual rights as an ongoing process, 
the following section reflects on the socio-political significance of international discourse.

\section{International contestations over sexual rights}

The participation of non-governmental organizations within the United Nations and in other international forums increased drastically from the 1960s to the 1990s. From 1968, when only 53 NGOs participated as consultants at the Teharan International Conference on Human Rights, the number grew dramatically to 248 NGOs as consultants and 593 as participants in the 1993 Human Rights Conference in Vienna, although more than 1,400 NGOs attended the conference unofficially. Another drastic change in participation was witnessed in the rise from 6,000 people attending the Mexico City Conference for International Women's Year in 1975 to the 13,500 people attending the NGO forum for the UN Decade on Women in Nairobi in 1985. The number of attendants to the Beijing NGO forum in 1995 grew to 300,000 (Clark; Friedman; Hochestetler, 1998). Not only the numbers, but the type of participation also changed, from having NGO representatives as observers in 1968, to the development of organized preparatory conferences in Nairobi in 1985 (Clark; Friedman; Hochestetler, 1998). The nature of the international interaction between NGOs also changed, as the power of negotiation of NGOs from the Global South (including Latin American, Africa and Asia) changed from listeners and observers to proactive agents, networking and lobbying for specific issues Notable also were the alliances formed between countries of the Global North and South. The role of NGOs questioning gender inequalities became more allied and their participation in drafting conference papers was stronger.

In 1993, both the World Conference on Human Rights held in Vienna and the United Nations' Declaration on the Elimination of Violence Against Women explicitly condemn gender-based violence and related human rights violations (Gruskin, 2000; Petchesky, 2000; Sadik, 2000). Because they initiated the international discourse of sexual violence as a human rights violation on a global level, these are particularly notable references (Petchesky, 2000; Narrain, 2001). The International Conference on Population and Development (ICPD), held in Cairo in 1994 is recognized as a watershed moment in further developing the concept of sexual rights by including not only protection from harm but also hinting at a notion of 'positive rights' (Klugman, 2000; Petchesky 2000, 2003). 
In fact, the term "sexuality" was first mentioned at the ICPD conference, where the definition of sexual health was also extended beyond the decision to reproduce, giving more attention to sexual satisfaction and to the health of interpersonal relations (Petchesky 2000). The Programme of Action (POA) produced at this conference recognizes sexual education for adolescents as important for "positive and responsible" sexual experiences, and it provides policy recommendations that consider diversity in family structures. (ICPD 5.1, 5.2; Petchesky 2000). The POA did not mention, however, any concept of freedom for diverse sexualities, remaining a hetero-centric text (Copelon; Petchesky, 1995; Petchesky, 2000).

The definition of sexual rights in the international human rights arena was further discussed at The Fourth World Women's Conference in Beijing (1995). Although sexual rights advocates pushed for the recognition of sexual diversity and sexual orientation in the Platform for Action, conservative delegates prevented the inclusion of a concept of 'sexual rights' that was not centered on heteronormative values. In the final document the term 'sexual rights' was excluded and replaced with the 'human rights of women', and the responsibility and freedom of women to decide in "matters related to their sexuality" was one of the most significant advances made at this conference. (Petchesky, 2000). Both the conference in Cairo (1994) and in Beijing (1995) undeniably initiated a discussion about the protection from harm (particularly for women). But these conferences foretold the discursive difficulties in wording of international documents that continues until today, particularly around highly polemical issues related to sexual diversity and pleasure. This begs the question: Are these battles of discourse reflexive of what people are experiencing, understanding, and claiming as their 'rights' on the local level? It is perhaps the lack of credible commitment to the recognition and enforcement of sexual rights on the global level that makes it so difficult to protect, let alone celebrate, sexual diversity on the local level.

After the conferences in Cairo (1994) and Beijing (1995) the debates about sexual rights carried over into a range of follow-up activities, such as Cairo +5 and Beijing +5 and other intergovernmental meetings. In Cairo +5 , in 1999, the discussions about sexuality education and adolescents' access to sexual and reproductive services carried over, receiving greater criticism from delegates from traditionalist and conservative countries (Corrêa; Sen, 1999). In Beijing +5 , the opponents of extending the scope of sexual rights attempted to stall the adoption of a final document, again in order to vanquish any language 
addressing discrimination based on sexual orientation and other issues related to sexuality. When terms such as "gender-sensitive" or "diversity of women" were mentioned, for example, Islamic countries demanded a "precise definition" of these terms, because they could strategically be interpreted to extend rights to homosexuals or open a Pandora's Box for women's liberation (Corrêa; Parker, 2003). One salient strategy that conservatives use often is to attach issues that clearly threaten the moral fiber of their constituents - for example, by associating the women's movement with the promotion of prostitution, sex trafficking, pornography, and pedophilia (Corrêa; Sen, 1999; Girard, 2004).

The tensions between the women's movement, the HIV/AIDS movement, the LGBT movement, on one hand, and delegates from conservative countries and institutions continued to resurface. In March 2001, when the Commission on the Status of Women debated 'Women and AIDS" in preparation for UNGASS, the delegates from the United States emphasized abstinence from sex until marriage as the most effective way to prevent HIV/AIDS. Once again the politics of identity fragmentation and targeting was the dominant game played on the international arena, where debates about what groups should be identified in the text was a distinct point of contention: Conservatives and traditionalists vehemently resisted the mention of sex workers, drug user, and men who have sex with men (Corrêa; Parker, 2003). It is counter-intuitive that these groups, which have been 'classified' as most vulnerable to the HIV/ AIDS epidemic, are essentially excluded and arguably demonized by opponents to sexual rights on the international arena.

Opponents of sexual rights have proactively attempted to exclude groups that advocate for sexual diversity from the international dialogue. A paradigmatic example of the this type of exclusion was witnessed at the roundtable on Human Rights organized by the Joint United Nations Programme on HIV/AIDS (UNAIDS) in June 2005, where nine member states officially objected to the participation of a delegate that represented the International Gay and Lesbian Human Rights Commission (IGLHRC) and the Health GAP coalition (a group advocating for access to treatment for HIV/AIDS). After voting, the group approved the participation of IGLHRC. The resulting document from this roundtable, the "Declaration of Commitment on HIV/AIDS - Global Crisis Global Action" was considered a step towards the legitimization of the discourse of sexual rights at the international level, especially since the debates during this conference were disseminated world-wide through by the media. 
In sum, international debates related to sexual autonomy began with the protection of women from violence, then leading a discussion on the importance of (hetero)sexual education, and even to some acceptance of diverse (heterosexual) family forms. But sexual diversity and sexual pleasure remain silenced and overshadowed by the powers of shaming and repudiation from traditionalist and fundamentalist 'actors'. These conservative 'actors' include not only delegates sitting at international conferences discussing particularities about the wording of official documents, but they sit at the family dinner table, in community boards and at the head of the classroom. And the global-discursive level differs from that of lived experience. If the global dialogue has only begun to recognize the freedom of women over their own bodies, it is needless to say that the official documents that result from most international debates still deem non-heterosexual sexualities as dangerous aberrations that belong nowhere near the discussion table.

There have been few research projects to evaluate the impact of Cairo (1994) and succeeding conference on sexual and reproductive rights on the country level. Some analysis does exist assessing the impacts of Cairo (1994) on policies in several countries with distinct economic, political, and socio-cultural environments. Hardee et al. (1999) evaluate the progress of national policy in eight countries, namely Bangledesh, Ghana, India, Jamaica, India, Jordan, Nepal, Peru and Senegal. Over a five year period using qualitative methods, the POLICY Project interviewed government officials, academics, donor institutions, non-governmental organizations, and grassroots groups and health providers (Hardee et al., 1999). The POLICY Project used indicators such as the adoption of the ICPD definition of reproductive health, the implementation of a national program, and the state-level mobilization of resources, and how services were being implemented in order to qualify the degree to which each of the case studies adhered to the suggestions of the Programme of Action (Hardee et al., 1999). The study found that Bangladesh, with the participation of variety of stakeholders from grassroots groups to the Ministry of Health and Family Welfare, restructured its previously vertical program to adopt of an "integrated service delivery system" with a "client centered package of essential services" (Hardee et al., 1999, p. S3). In India, however the involvement of nongovernmental organizations is limited, opponents to the move away from the demographic and population based approach thwarted significant efforts to adopt unfamiliar interventions for sexually transmitted diseases (such as HIV), and resources were not available to implement free contraceptive measures. In 
Nepal, although there was some U.S. technical support, there was little participation from non-governmental stakeholders. As a representative stated, "Government does not truly consider NGOs their partners. Such talk is jargon." (quoted from Hardee et al., 1999, p. S4). Due to lack of financial resources, Nepal was not able to mobilize a significant reaction to the ICPD recommendations. In Jordan, a medical technician from the United States claimed that there was not a real opposition to the reproductive health approach (maternal and child care). The meaning of reproductive health is misunderstood due to "lack of awareness", as the medical technician explains that health post workers "may be baffled if you ask about reproductive health if they have not read the guidelines" (quoted from Hardee et al., 1999, p. S5). Thus, from this evaluation it is evident that much of the conversations that resulted at the national and local level centered on reproductive health, leaving out of the agenda the more polemical issues related to sexuality and sexual diversity. The difficulties expressed in understanding international and national jargon is also noteworthy because local interpretations and programmatic implementation are what affect people most personally.

\section{How the global maps onto the local}

While the articulation of sexual rights as part of international and intergovernmental discourse (on the global playing field) has been extremely important in recent years, it is also essential to understand the ways in which locally defined movements, communities and cultures have articulated their own notions of what we call sexual rights and sexual citizenship. It is also important to note that the term "sexual rights" is defined, understood, and articulated in diverse local terminologies. Here we consider several issues related to sexuality and sexual rights in a few contexts in order to present diversity and similarities depending on contextual factors. The focus of these examples of how the global discourse reaches local settings is primarily on women's sexual and reproductive rights, since the international discourse has been most successful in including these within official documents.

First, feminist networking that occurred in the 1990s due to international conferences allowed local women's rights activists to access and exchange ideas and strategies or repertoires of contention (Tarrow, 1998) for promoting change across national boundaries, giving them the legitimacy to affect policies and cultural norms (Alvarez, 2000; Baden; Goetz, 1997). Political opportunity 
structures (Tarrow, 1998) have influenced the way that local grassroots activists have networked. This type of movement of ideas across country boarders has been referred to as diffusion with reference to social movements (Chabot; Duyvendak, 2002) and as the formation of ideoscapes (Appadurai, 1996). The exchange of local cultural realities across boarders can broaden local horizons, potentially bringing scrutiny to previously unquestioned norms, spurring the growth of collective identities, inspiring transnational solidarity, and increasing media coverage of contention. On the flipside, this negotiation between local and global articulations of "sexual rights" is paradoxical. Because these terms and recommendations resulted from "incorporating the concerns of very different constituencies there are today numerous 'others' and multiple perspectives" (Obermeyer, 1999) - creating the potentiality of excluding the voices new grassroots groups and of marginalized NGOs with lesser representation.

In Nigeria, the local women's mobilization (which emerged partly in resistance to the economic disparities brought about by the neo-liberal project privatizing public services) has focused primarily on resisting "the denial of women's political rights, restricted access to justice, violence against women, the need for reproductive health and rights, struggles for legal rights and literacy, and against human trafficking” (Pereira, 2002, p. 794). Two major problems that women's groups face are the lack of attention to these issues in the public sphere and the scarcity in funding to publicize these problems in order to mobilize the agenda of women's groups (Pereira, 2002). The impact of international conferences on the visibility and publicity problems faced by local women's organizations was evident in the National Tribunal on Violence Against Women, which was modeled after the International Tribunal on Violence Against Women in 1993 at the United Nations. In this tribunal, women spoke about their experiences with violence before facilitators and a panel of judges. This is a prime example of how international conferences can address local issues headon. Subsequently, the Legislative Advocacy Coalition of Violence Against Women (LACAW) addressed violence against women at a national conference assembled by the International Human Rights Law Group. The purpose of this conference was to mobilize and network NGOs working against "traditional" norms that perpetuated domestic violence against women and inheritance rights. The conclusion of the conference was the formation of a coalition to push for policy changes, while the group also recognized the importance of changing cultural norms and administrative processes though community mobilization and raising consciousness (Pereira, 2002). 
Although the case study of women's mobilization in Nigeria seems largely optimistic, there are several factors that these conventions and their goals did not take into account, including "differences of identity, geographic location, age, and economic status” (Pereira, 2002, p. 796). More importantly, the conventions were criticized for focusing to much on publicity and not enough on needs assessment. One of the areas that was not acknowledged was the subject of 'sexual rights', an area that affects primarily young women and girls (revealing an ageist bias) because there is a lack of education for young girls on how to claim the right to accept or reject sexual intercourse (Pereira, 2002). In other words, these national forums focused more on the protection from harm (negative rights) and avoided discussions about education for young women (considerably a positive right). The lack of attention to the sexual rights and health of young girls has strong implications on their vulnerability to sexually transmitted diseases, including HIV/AIDS.

In addition to the neglect for the sexual rights of young girls, there are other factors such as ethnic cleavages that diminish the effect of international discourses of sexual rights on local realities in places such as Nigeria. Politicians in countries with distinct ethnic divides have a tendency to base political decisions on ethnic identities, which are highly linked to ideologies of tradition and custom (Pereira, 2002). In Nigeria, as in many countries, the woman's body carries a heavy burden in the realm of preserving tradition, and therefore, women's rights are often subverted to the preservation of tradition as a political strategy (Pereira, 2002). Contextual factors such as ethnic fractionalization and the citizenship of young women are crucial in determining the leverage of international mobilization around sexual rights. In addition, the it is important to note that the notion of protection against violence is still the prominent platform in most national contexts, where sexual diversity or pleasure are not legally or culturally acceptable as rights.

Some literature has directly addressed the political issues involved in the identity politics of southern African nationalism and the role of organizations that address gender based violence, gay rights, and sexual health issues (Kraak, 1998). These organizations have challenged patriarchy and the nuclear family, although solidarity weak due to identity fragmentation (Kraak, 1998). Contention around the nuclear family is particularly critical because it not only relates to ideological notions of tradition, but it has direct linkages to economic policy and government assistance (Kraak, 1998). This creates a strong tension between the diversity of family forms as addressed in international discourses and the 
way that local political, economic, and socio-cultural realities shape policies related to sexual rights, especially with regard to systems of patriarchy that thrive on gender inequities.

On a more positive note, the discourse of about sexuality in the global south has reached the ground not only through internet forums as described earlier but also through sexuality helplines. Data collected through the TARSHI helpline, which is based in New Delhi, India, was used to analyze the language used by men and women to talk about sex and their sexual experiences and bodies (Chandiramani, 1998). The data presents demographic information about the callers who use the helpline, frequencies of questions and themes that callers bring up, as well as information about counselor training, and call and documentation procedures. The helpline was developed to help women by providing information and a safe outlet to discuss issues around sexuality. Although most callers are men, the Chandiramani (1998) argues that the helpline has effected positive change for women indirectly, providing information and education to men about issues including basic anatomy, female pleasure, and sexual violence. In fact, the study found that some male callers and their partners have benefited from information about foreplay, that they postponed first intercourse in an arranged marriage until both partners felt ready, and that some women callers reported being referred by their male partners (Chandiramani, 1998).

After taking a glimpse of what is occurring at the local and national levels to further the sexual rights agenda, the language used in international dialogues has served as leverage for policy recommendations. But as this discourse trickles down through multiple levels of socio-cultural interpretations, and as it interacts with political and economic structures (especially at the level of implementation), certain portions of it are prioritized by diverse segments of civil society. Negative sexual rights have been the priority of more localized constituencies and grassroots movements. This is not surprising considering the level of sexuality- and gender-related violence present in the world today, in large part due in part to fundamentalists and conservative counter-movements that have increasingly emerged with dense local networks and focused ideological agendas. Strategically, the 'sexual rights movement' has tended to prioritize redressing harms before more (or any) work can be done to celebrate sexuality as an innate human freedom. 


\section{Conclusions and next steps}

In this paper we have explored how sexual rights are dialectically framed through global work as well as how this work is interpreted, articulated and utilized by emerging local movements and communities where people are actually experiencing their sexual lives. The extent to which international definitions and discourses of sexual rights can help to strengthen local mobilization depends on political and economic opportunity structures, cultural norms, and the formation of collective identities. We are still left with the question of whether a 'sexual rights movement' can be forged between different social movements that are struggling for unique aspects of what falls under the category of sexual rights as defined by international dialogues. In order to work towards a more unified movement based on solidarity and social justice, rather than on the politics of identity, we must continue to extend international networks as well as deepen local roots. Sexual rights are unique because they are enforced or denied by the state as well as by religion, culture, science, communities, and so forth. The advancement of sexual rights therefore requires legal and formal institutional changes as well as socio-cultural transformations. As with any right, sexual rights must be protected (or enabled) as well as claimed by the citizen.

Therefore, a clearer understanding of what constitutes a sexual right must be constructed by assessing local needs and democratizing information about the rights and responsibilities of sexual citizens. As part of a bundle of fundamental rights, sexual rights are often given less priority to politicians and to ordinary citizens than economic or political rights. We must avoid the fallacy of conceptualizing sexual rights as separate from economic or political rights because we can be denied these, more socially enshrined rights, because our sexualities and our genders are inscribed in our bodies, beliefs, and actions. Discourses stimulated by activists and academics are defining an ideal ethics of sexual rights, while in the quotidian many aspects of our sexualities continue to be strategically repressed. The consolidation of a social movement around sexual rights, more broadly, will be a longer-term project. Already the agenda has been identified, if we accept this differentiation of negative and positive sexual rights. The linkages between elites, international activists, states, and grassroots movements provides optimism for the formation of a meaningful social movement advocating for sexual rights with socio-cultural as well as structural fields of contention. 


\section{References}

AFROL NEWS. Desmond Tutu: "homophobia equals apartheid". 2006. At: <http://www.afrol.com/articles/13584>. Accessed on: July 72006.

ALVAREZ, S. Translating the global: effects of transnational organizing on local feminist discourses and practice in Latin America. Cadernos de Pesquisa, n. 22, p. 1-27, 2000.

ALVAREZ, S.; DAGNINO, E.; ESCOBAR, A. Introduction: the cultural and the political in Latin American social movements. In: ALVAREZ, S.; DAGNINO, E.; ESCOBAR, A. (Ed.). Cultures of politics/politics of culture: re-visioning Latin American social movements. Boulder, CO: Westview Press, 1998. p. 129.

APPADURAI, A. Modernity at large: cultural dimensions of globalization. Minneapolis: University of Minnesota Press, 1996.

ARNOLD, E. M. et al. The effects of abstinence-based sex education program on middle school student's knowledge and beliefs. Research on Social Work Practice, v. 9, n. 1, p. 10-24, 1999.

BADEN, Sally; GOETZ, Anne Marie. Debating discourses, practising feminisms. Feminist Review, n. 56, p. 3-25, Summer 1997.

BENFORD, R. D.; SNOW, D. Framing processes and social movements: an overview and assessment. Annual Review of Sociology, n. 26, p. 611-639, 2000.

BERKMAN, A. et al. A critical analysis of the Brazilian response to HIV/ AIDS: lessons learned for controlling and mitigating the epidemic in developing countries. American Journal of Public Health, v. 95, n. 7, p. 1162-1172, 2005.

BOURDIEU, P. Practical reason: on the theory of action. Cambridge: Polity Press, 1998.

BROWN, P. et al. Embodied health movements: new approaches to social movements in health. Sociology of Health \& Illness, v. 26, n. 1, p. 50-80, 2004.

CALHOUN, C. (Ed.). Social theory and the politics of identity. Cambridge, MA: Blackwell, 1994. 
CAMERON, E. Sexual orientation and the Constitution. South African Law Journal, v. 110, p. 450, 1993.

CAMERON, E. Constitutional protection of sexual orientation and African conceptions of humanity. South African Law Journal, v. 118, n. 4, p. 642, 2002.

$\mathrm{CASH}, \mathrm{K}$. et al. Telling them their own stories: legitimizing sexual and reproductive health education in rural Bangladesh. Sex Education, v. 1, n. 1, p. 43-57, 2001.

CASTELLS, M. The rise of the network society. Cambridge, MA: Blackwell Publishers, 1996.

CASTELLS, M. The power of identity. Malden, MA: Blackwell Publishers, 1997.

CASTELLS, M. End of Millenium. Malden, MA: Blackwell Publishers, 1998. CHABOT, S.; DUYVENDAK, J. W. Globalization and transnational diffusion between social movements: reconceptualizing the dissemination of the gandhian repertoire and the "coming out" routine. Theory and Society, v. 31, n. 6, p. 697-740, 2002.

CHANDIRAMANI, Radhika. Talking about sex. Reproductive Health Matters, v. 6, n. 12, p. 76-86, 1998.

CLARK, A. M.; FRIEDMAN, E. J.; HOCHSTETLER, K. The sovereign limits of global civil society: a comparison of NGO participation in UN World Conferences on the Environment, Human Rights, and Women. World Politics, v. 51, n. 1, p. 1-35, 1998.

COPELON, R.; PETCHESKY, R. Toward an interdependent approach to reproductive and sexual rights as human rights: reflections on the ICPD and beyond. In: SCHULER, M. (Ed.). From basic needs to basic rights: women's claim to human rights. Washington, DC: Women Law and Development International, 1995. p. 343-368.

CORRÊA, S.; PARKER, R. Sexuality, human rights, and demographic thinking: connections and disjunctions in a changing world. Sexuality Research and Social Policy, v. 1, n. 1, p. 15-38, 2003. 
CORRÊA, S.; PETCHESKY, R. Reproductive and sexual rights: a feminist perspective. In: SEN, G.; GERMAINE, A.; CHEN, L. (Ed.). Population policies reconsidered: health, empowerment, and rights. Boston, MA; New York, NY: Harvard University Press; International Women's Health Coalition, 1994. p. 107-122.

CORREAA, S.; SEN, G. Cairo+5: moving forward in the eye of the storm. Social Watch, n. 3, p. 81-86, 1999.

FARMER, P.; CONNORS, M.; SIMMONS, J. (Ed.). Women, poverty and AIDS: sex, drugs and structural violence. Monroe, Maine: Common Courage Press, 1996.

FISCHER, W. F. Doing good? The politics and antipolitics of NGO practices. Annual Review of Anthropology, n. 26, p. 439-464, 1997.

FOLEY, M. W.; EDWARDS, B. The paradox of civil society. Journal of Democracy, v. 7, n. 3, p. 38-52, 1996.

FORD, N.; ODALLO, D.; CHORLTON, R. Communication from a human rights perspective: responding to the HIV/AIDS pandemic in Eastern and Southern Africa. Journal of Health Communication, v. 8, n. 6, p. 599-612, 2003.

FREIRE, P. Education for a critical consciousness. New York: Continuum Publishing, 1973.

GAMSON, Josh. Silence, death, and the invisible enemy: AIDS activism and social movement newness. Social Problems, v. 36, n. 4, p. 351-365, 1989.

GIDDENS, A. The consequences of modernity. Stanford, CA: Stanford University Press, 1990.

GIDDENS, A. Modernity and self-identity: self and society in the Late Modern Age. Cambridge, UK: Polity Press, 1991.

GIRARD, F. Global implications of U.S. domestic and international policies on sexuality. New York: International Working Group on Sexuality and Social Policy, 2004. (No. IWGSSP Working Paper No. 1). At: <http:// ww w. health s ciences.columbia.edu/dept / s p h / c g s h / IWGSSPWorkingPaper1English.pdf>. Accessed on: Oct. 12004.

GRUSKIN, S. The conceptual and practical implications of reproductice and sexual rights: how far have we come? Health and Human Rights, v. 4, n. 2, p. 1-6, 2000. 
HARDEE, K. et al. Reproductive health policies and programs in eight countries: progress since Cairo. International Family Planning Perspectives, n. 25 (Suppl), p. S2-S9, 1999.

HARVEY, D. The condition of postmodernity: an enquiry into the origins of cultural change. Oxford: Blackwell Publishers, 1989.

HEYWOOD, M. The AIDS epidemic in Africa: openness and human rights. SAfAIDS News, v. 7, n. 1, p. 2-7, March 1999. At: <http://www.safaids.org.zw/ publications/1999\%20Vol\%207\%20No\%201.pdf>. Accessed on: Nov. 232005.

JONES, J. Money, sex and the religious right: a constitutional analysis of federally funded Abstinence-Only-until-Marriage sexuality education. Creighton Law Review, v. 35, n. 4, p. 1075-1106, 2002.

KLUGMAN, B. Sexual rights in Southern Africa: a Beijing discourse or a strategic necessity? Health and Human Rights, v. 4, n. 2, p. 144-173, 2000.

KRAAK, G. Class, race, nationalism and the politics of identity: a perspective from the South. Development Update, v. 2, n. 2, 1998. At: <http:// www.interfund.org.za/vol2no21998.html>. Accessed on: Sept. 102003.

LAMBERTS-BENDROTH, M. Fundamentalism and the family: gender, culture, and the American Pro-Family Movement. Journal of Women's History, v. 10, n. 4, p. 35-54, 1999.

MALUWA, M.; AGGLETON, P.; PARKER, R. Stigma, discrimination and HIV/AIDS in Latin America and the Caribbean. Washington, D.C.: InterAmerican Development Bank, 2003.

MANN, J.; TARANTOLA, D.; NETTER, T. AIDS in the world. Cambridge, MA: Harvard University Press, 1992.

MARTY, M. E. Fundamentalism as a social phenomenon. Bulletin of the American Academy of Arts and Sciences, n. 42, p. 15-29, 1988.

MCADAM, D.; MCCARTHY, J.; ZALD, M. Comparative perspectives on social movements. Cambridge: Cambridge University Press, 1996.

NARRAIN, A. Human rights and sexual minorities: global and local contexts. Law, Social Justice and Global Development, n. 2, p. 1-19, 2001.

OBERMEYER, C. M. The cultural context of reproductive health: implications for monitoring the Cairo agenda. International Family Planning Perspectives, n. 25 (Suppl), p. S50-S55, 1999. 
PARKER, R. Empowerment, community mobilization, and social change in the face of HIV/AIDS. AIDS, n. 10, p. S27-S31, 1996.

PARKER, R. Sexual rights: concepts and actions. Health and Human Rights, v. 2, n. 3, p. 31-37, 1997.

PARKER, R. Na contramão da Aids: sexualidade, intervenção, política. Rio de Janeiro: Abia, 2000.

PARKER, R. Sexuality, culture and power in HIV/AIDS research. Annual Review of Anthropology, n. 30, p. 163-179, 2001.

PARKER, R.; AGGLETON, P. HIV and AIDS-related stigma and discrimination: a conceptual framework and implications for action. Social Science and Medicine, v. 57, n. 1, p. 13-24, 2003.

PARKER, R.; BARBOSA, R. M.; AGGLETON, P. (Ed.). Framing the sexual subject: the politics of gender, sexuality and power. Berkeley: University of California Press, 2000.

PARKER, R. et al. Global transformations and intimate relations in the 21st century: social science research on sexuality and the emergence of sexual health and sexual rights frameworks. Annual Review of Sex Research, n. 15, p. 362399, 2004.

PATEL, N. Talking about pleasure: how does language make a difference. Women in Action, n. 1, p. 66-74, 2006.

PINTAGUY, J. Bridging the local and the global: feminism in Brazil and the International Human Rights Agenda. Social Research, v. 69, n. 3, p. 805-820, 2002.

PEREIRA, C. Configuring "global”, "national," and "local” in governance agendas and women's struggles in Nigeria. Social Research, v. 69, n. 3, p. 781-804, 2002.

PETCHESKY, R. Sexual rights: inventing a concept, mapping an international practice. In: PARKER, R.; BARBOSA, R. M.; AGGLETON, P. (Ed.). Framing the sexual subject: the politics of gender, sexuality and power. Berkeley: University of California Press, 2000. p. 81-103.

PETCHESKY, R. Global prescriptions: gendering health and human rights. London: Zed Books, 2003. 
POLLETTA, F. It was like a fever...: narrative and identity in social protest. Social Problems, v. 45, n. 2, p. 137-159, 1998.

POLLETTA, F.; JASPER, J. Collective identity and social movements. Annual Review of Sociology, n. 27, p. 283-305, 2001.

RATZINGER, J. Considerations regarding proposals to give legal recognition to unions between homosexual persons. 2003. At: <http:// www.vatican.va/roman_curia/congregations/cfaith/documents/ rc_con_cfaith_doc_20030731_homosexual-unions_en.html>. Accessed on: July 242004.

RATZINGER, J. (2004). Letter to the bishops of the catholic church on the collaboration of men and women in the church and in the world. 2004. At: <http://www.vatican.va/roman_curia/congregations/cfaith/documents/ rc_con_cfaith_doc_20040731_collaboration_en.html>.Accessed on: July 232004.

SADIK, N. Progress in protecting reproductive rights and promoting reproductive health: five years since Cairo. Health and Human Rights, v. 4, n. 2, p. 7-15, 2000 .

SAIZ, I. Bracketing sexuality. New York: International Working Group on Sexuality and Social Policy, 2005. (IWGSSP Working Paper No. 2).

TARROW, S. Power in movement: social movements and contentious politics. Cambridge: Cambridge University Press, 1998.

WATERS, M. Globalization. London: Routledge, 1995.

WORLD HEALTH ORGANIZATION. Gender and reproductive health glossary. 2002. At: <http://www. who.int/reproductive-health/gender/ glossary.html>. Accessed on: Oct. 12004. 